doi:10.1017/aju.2017.90

\title{
SYMPOSIUM ON COMPARATIVE FOREIGN RELATIONS LAW
}

\section{FOREIGN RELATIONS LAW AND GLOBAL CONSTITUTIONALISM}

\author{
Anne Peters*
}

This essay draws upon the perspectives, concepts, and tools developed in the literature on global constitutionalism as support for "normalizing" foreign relations law-that is, presumptively subjecting foreign relations actions to the constitutional and other legal standards that apply to domestic actions. ${ }^{1}$

\section{Global Constitutionalism}

Global constitutionalism proceeds from the premise that we live in a world in which international law (including the secondary law produced by international organizations and many forms of "soft law") may have strong repercussions on individuals' lives, and may affect their freedom, dignity, and wellbeing. From the perspective of individuals, the consequences of some international legal instruments (for example targeted sanctions imposed by the UN Security Council) do not always differ categorically from the effects of domestic laws or executive measures although the repercussions are usually weaker and less direct. The same is true for the extraterritorial effects of legal measures taken by one state for the population of other states. For example, agricultural subsidies granted in one state may contribute to the destruction of markets and thus affect the livelihood of entire populations in other states.

The impacts of international law and foreign law on the domestic realm have (in combination with other factors) triggered changes in domestic law itself. Leaving aside technical questions of hierarchy, incorporation, direct effect, and of monism and dualism, we can roughly say that, today, the internal law of any given state is to some extent shaped by international law, and also by the law of other states. This shaping may be beneficial, from the standpoint of constitutionalism, e.g., when international human rights standards are brought into national constitutions. ${ }^{2}$

On the other hand, the transnational and extraterritorial effects, both of international law and of domestic law, may also be pernicious because they may result in a "hollowing out" of domestic constitutions. Even if a given state's constitution requires state acts to have a sufficient legal basis, mandates democratic procedures of lawmaking, and offers access to courts against acts of public authority, these constitutionalist guarantees do not cover the measures taken by international organizations and other states. Put the other way round, the traditional constitutional functions, such as guaranteeing the rule of law and the protection of human rights, have to some degree escaped the confines of the nation state, and thereby also the umbrella of the domestic constitutions.

* Director at the Max Planck Institute for Comparative Public Law and International Law Heidelberg (Germany).

${ }^{1}$ See, e.g., Ganesh Sitaraman \& Ingrid Wuerth, The Normalization of Foreign Relations Law, 128 Harv. L. Rev. 1897 (2015).

2 Anne Peters, The Globalisation of State Constitutions, in New Perspectives on the Divide between National and International Law 251 (Janne Nijman \& André Nollkaemper eds., 2007).

\footnotetext{
The American Society of International Law and Anne Peters (C) 2017. This is an Open Access article, distributed under the terms of the Creative Commons Attribution licence (http://creativecommons.org/licenses/by/4.0/), which permits unrestricted re-use, distribution, and reproduction in any medium, provided the original work is properly cited.
} 
On the normative premise that - as a general matter-constitutionalist achievements are worth upholding, the diagnosis of a running aloof of domestic constitutional guarantees through the scooping out of national constitutions leads to the normative quest for "compensatory" or "supplementary" constitutionalism: ${ }^{3}$ In our contemporary world, the achievements of constitutionalism will get lost if they are not projected to the international and transnational sphere. This also implies that foreign relations law should be informed by constitutionalism. Measures taken by a constitutional state in its foreign relations should, from this perspective, pay due regard to the rule of law, human rights, democracy, and to the fourth limb, social protection. Also, states should relate those principles (and the mechanisms that realize them) not primarily to the nation but to the international community at large.

Global constitutionalism also contends that in fact, parts of international law-in their interplay with domestic law - can usefully be redescribed as indeed forming constitutional bits and pieces and roughly and tentatively fulfilling a constitutionalist program, shared explicitly or implicitly by numerous states. The program is reflected in constitutionalist principles, notably the rule of law, human rights, and democracy (the constitutionalist "trinity" supplemented by the principle of social protection.

The redescription of the global legal realm in constitutional terms does not include the assertion that we see an international "Constitution" with a capital C. There is no global "superconstitution" that would lie both "above" domestic state constitutions and that would completely embrace all separate international regimes. Rather, we see fragments and case-law that together might be qualified as a body of global constitutional law that has a particular normative "constitutional" status and that fulfills specific constitutional functions. ${ }^{5}$

For example, international organizations have been pressured to respect international human rights, ${ }^{6}$ to become more transparent, ${ }^{7}$ to allow for civil society participation, and to grant access to justice. ${ }^{8}$ Global constitutional law substance may be dispersed vertically across different levels of the law (both international law and domestic law), horizontally across "regimes" or issue areas, and maybe even across the public_-private realms.

\section{Treaty-Making}

From the perspective of global constitutionalism, the values protected in the domestic lawmaking process should also be protected in international treaty-making. International treaties are instruments of governance that deploy legal and practical effects on humans' lives. The principle of democracy demands that such acts be subject to the consent of the people that are governed by them.

Consent of the state as a whole is normatively insufficient. Because states are, unlike individuals, not entities in their own right, but institutional resources for human beings, their approval matters only to the extent that it transports their populations' consent. However, the mediation of approval through states is deficient for three reasons.

\footnotetext{
${ }^{3}$ Anne Peters, Compensatory Constitutionalism: The Function and Potential of Fundamental International Norms and Structures, 19 LEIDEN J. INT'L L. 579 (2006); Jeffrey L. Dunoff \& Joel P. Trachtman, A Functional Approach to International Constitutionalization, in RULING THE WorLD? Constitutionalism, International Law, and Global Governance 3, 14-18 (Jeffrey L. Dunoff \& Joel P. Trachtman eds., 2009).

${ }^{4}$ Mattias Kumm et al., How Large is the World of Global Constitutionalism?, 3 Global Constrtutionalism 1, 3 (2014).

${ }^{5}$ Thomas Kleinlein \& Anne Peters, International Constitutional Law, in Oxford Bibliographies In InTERnational Law (Anthony Carty ed., 2d ed. 2017).

${ }^{6}$ See, e.g., Sigrun I. Skogly, The Human Rights Obligations of the World Bank and the International Monetary Fund (2001).

7 See, e.g., The World Bank Policy on Access to Information (July 1, 2010); Regulation (EC) No. 1049/2001 of the European Parliament and of the Council of 30 May 2001 Regarding Public Access to Documents, 2001 O.J. (L 145) 43.

${ }^{8}$ For employees of the organizations, internal complaint mechanisms in the form of administrative tribunals have been improved in the past decade. The International Monetary Fund established an Administrative Tribunal in 1994; an EU Civil Service Tribunal was established in 2005; the UN Administrative Tribunal was transformed into a two-tiered system with a United Nations Appeals Tribunal in 2009.
} 
First, many authoritarian states do not represent their citizens in a formally democratic fashion. In consequence, treaties concluded with or among undemocratic states do not enjoy the full consent of the governed. Second, even the consent of states that can be duly said to represent their citizens is often flawed because of the unequal bargaining power of states. Although fraud, corruption, personal coercion, and the threat or use of force vitiate state consent (see Articles 49-52 of the Vienna Convention on the Law of Treaties), other instances of undue pressure are not precluded.

Third, and most importantly, many treaty commitments, especially modern ones, are not concrete and static, but general and dynamic. State consent here amounts to a blanket permission that has little legitimizing force. This is especially true for treaties establishing international institutions that monitor behavior, interpret imprecise and incomplete texts, and develop new norms. These treaty regimes cannot be meaningfully said to be covered by the original consent.

In recent decades, this democratic gap has been felt, and it has been filled to some extent. From the perspective of global constitutionalism, further efforts to improve the democratic basis of international treaty-making are warranted. Steps can be taken both on the national and on the international level. The role of national parliaments could be strengthened, such as through early information about treaty negotiations or by allowing parliaments to modify the contents of a treaty text agreed upon by the executives. On the international plane, the predominance of the state executives can be rectified by involving national parliaments in the negotiation, conclusion, and the expression of consent to be bound by a treaty.

The involvement of civil society organizations (CSOs) also deserves further strengthening. So far, these organizations do not enjoy treaty-making power, and do not have any official negotiating role. Nevertheless, their direct lobbying at international conferences and their drafting activities have been a decisive factor in the adoption or failure of important recent multilateral treaties. Importantly, the CSOs enjoy a "participatory status" in most international organizations, and have a formal role in the elaboration of secondary law and various governance activities. The input of CSOs in the making of treaty law, secondary law, and soft law is laudable from a constitutionalist perspective. It improves the legitimacy of the process and of the outcomes, although CSOs do not enjoy any democratic mandate by (global) citizens. The role of CSOs is not to be representatives in a parliamentary sense, but to pursue single issues or special interests. They speak (or claim to speak) for vulnerable groups or otherwise voiceless entities, such as nature. This role requires giving CSOs a voice, but not necessarily a vote in the processes of treaty-making and the production of secondary law. The impact of voice in international lawmaking is sufficiently justified by the reputational and moral legitimacy of CSOs. Their vote, in contrast, would not be legitimate, both because they lack a democratic mandate, and because their typical selectivity of interests and one-issue-character makes them, unlike governments, unfit for package deals or compromises needed in treaty-making. Granting them a vote would therefore decrease the legitimacy of treaty-making.

\section{War Powers}

The German philosopher Immanuel Kant predicted that the spread of democratic governments would lead to world peace, because "if the consent of the citizens is required in order to decide that war should be declared (and in this constitution it cannot but be the case), nothing is more natural than that they would be very cautious in commencing such a poor game, decreeing for themselves the calamities of war." 9 The so-called "democratic peace thesis" has been confirmed empirically by contemporary international relations scholarship. It is a plain fact that

\footnotetext{
${ }^{9}$ Immanuel Kant, Perpetual Peace, in Perpetual Peace, and Other Essays on Politics, History, and Morals sec. II (First Definitive Article for Perpetual Peace) (1795).
} 
liberal democracies do not wage war against each other. ${ }^{10}$ (In contrast, democracies have in the past often made war against nondemocracies.)

Against this background, it seems desirable to strengthen not only democratic governance in general but also specifically in concrete decisions to deploy military force. This has in fact been done in several European states since the 1990s. In Austria, a law on parliamentary involvement was adopted in 1997. In Germany, the relevant case-law began in 1994, and a statute on the involvement of parliament requires approval of the German first parliamentary chamber for any deployment of German armed forces outside the country. ${ }^{11}$ A French constitutional amendment of 2008 grants the Assemblée Générale (the parliament's first chamber) a power of approval of the decision to use military force. In the United Kingdom, the constitutional reforms, initiated in 2006, stopped short of a codification of parliamentary powers in 2013.

The prerogative of the executive to use military force had been called into question only in the second half of the twentieth century, probably due to a combination of heightened democratic sensibilities and controversial military operations. In the United States, this occurred in connection with the Vietnam War in the 1960s and 1970s; in the United Kingdom, it was triggered by the Kosovo war of 1999. Most other Western states only use military force abroad as a part of collective security measures, and the adoption of statutes (e.g., in Austria) and the emergence of case-law (e.g., in Germany) thus occurred in the 1990s, when the Security Council for the first time authorized the use of military force and adopted economic sanctions monitored by military aircraft.

The need for a parliamentary decision on deploying military force is felt because ordinary people today are less ready to "sacrifice" young men and women for a public cause than in previous historic periods. The change of attitudes is exacerbated by the fact that military engagement is nowadays more often about "foreign" problems, not directly and immediately threatening the home state. The reluctance towards sacrifice (especially in foreign lands) has been met by some states with the abolition or suspension of a conscription-based army and its replacement through professionals (in the United States after the Vietnam War; in Germany in 2011). All in all, the decision to deploy military force is today perceived to be so important and costly that it warrants public debate, deliberation, and support by a democratic state's most directly accountable body.

But global constitutionalism also complicates this emphasis on parliamentary involvement. Was it-from the perspective of global constitutionalism-fair that legislators of a deploying state, for example thirteen members of the British House of Commons in 2013, could set in motion a chain of political decisions that (indirectly) affected the fate of thousands of civilians in Syria? ${ }^{12}$ Can we say that this was a "democratic" decision on the current state of the world in which the Islamic State is on the rise, and the entire region is profoundly destabilized? The fact that the votes of thirteen persons have made world politics (by stalling a military intervention for more than one year) ${ }^{13}$ illustrates the conundrum of democracy in multilevel governance. Inside the United Kingdom, the decisions might have represented the will of the British people, but did they duly take into account the interests of the Syrian civilians, or the global interest in suppressing a terror regime?

From a global democracy perspective, a purely executive decision to wage war (or to abstain from it) does not seem to be much less democratic than a parliamentary vote on that very matter in one state. A "true" democratic decision would seem to require the formal representation of the views of other states' inhabitants, notably of

10 Allan Dafoe, Statistical Critiques of the Democratic Peace: Caveat Emptor, 55 Am. J. PoL. ScI. 247 (2011).

${ }^{11}$ Parlamentsbeteiligungsgesetz [Parliamentary Participation Act], Mar. 18, 2005, BGBL. I at 775 (Ger.).

12 On August 30, 2013, the British House of Commons rejected (with 285 against 272 votes) two motions to deploy military force in Syria after a chemical weapons attack, based on the governmental proposition that the conditions for a humanitarian intervention in Syria were met.

13 The U.K. Parliament approved the motion on ISIL in Syria (based on UN SC Res. 2249) (House of Commons vote 397 to 223 (2 Dec. 2015 Parl Deb. HC (6th ser.) (2015) col. 490 (U.K.)). 
affected states (such as Syria). This leads to a quest for involvement of supranational bodies such as the parliamentary assemblies of international organizations ranging from NATO to OSCE. But even in these forums, the populations endangered by terror and civil strife have no say.

Yet, does it make sense to ask for democratic decision-making, for the consent of those who will probably be (transnationally) affected by or even subjected to a use of force- just as for other policy-decisions? ${ }^{14}$ The answer is a cautious "no," because the difference between making a treaty and deciding to use military force is that the latter decision is not only the expression of a political preference and an attempt to regulate, but an enforcement decision that involves extremely high costs for the acting state, including potentially the sacrifice of lives. The normative quest for taking into account global, other states', and foreign citizens' interests when making such a decision is less persuasive as in simple treaty-making. It is intuitively more acceptable that such a decision primarily concerns "us" and not "them," and that solidarity with "them" and with "their" problems is only limited. It is true, to stick to the example, that the Syrian population incurs costs and suffers harm through the nonintervention of third states. But this is a different type of harm than the costs incurred by the acting states. Only if the Syrians were in principle entitled to military aid (which is not the case, not even under a strict reading of the responsibility to protect) could a case for their democratic involvement in any decision on military action (or on abstention from such action) in the region be made.

In contrast, the decision of the polity that bears the costs of intervening with military means should be taken as democratically and open as possible. The stalling-effect of asking the citizens (through their parliaments), as predicted by Kant, may ultimately harm strangers. But this tragic consequence can in the long run only be avoided by transforming these polities into democracies, too.

\section{Conclusion}

In a world characterized by global flows of information and digital hyperconnectivity, global supply chains, intense global trade, foreign investment, and migration, global constitutionalism suggests that the point of departure of any analysis should be that foreign affairs are not a categorically distinct type of government activity and that international law (despite specific legal forms, persons, and institutions) is not categorically distinct from other law in terms of functions, effects, and notably its need of legitimacy.

From this it follows that global constitutionalism is skeptical about foreign relations law "exceptionalism." From a global constitutionalist perspective, exceptionalism results mainly in mitigating or downscaling constitutional demands, such as democratic procedures, respect for the rule of law and for human rights, and judicial review. Global constitutionalism holds that, prima facie, foreign relations actions and the law that governs them should be subject to the usual constitutional standards. Starting off from constitutional normalcy, the burden of explanation lies on those who advocate exceptional treatment.

${ }^{14}$ Robert Goodin, Enfranchising All Subjected, Worldwide, 8 INT'L THeOry 365 (2016). 